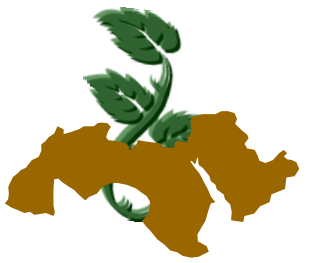

Arab Univ. J. Agric. Sci., Ain Shams Univ., Cairo, 23(1), 75 - 89, 2015

\title{
PERFORMANCE AND STABILITY OF SOME BREAD WHEAT GENOTYPES FOR GRAIN YIELD, PROTEIN AND GLUTEN CONTENTS UNDER DIFFERENT ENVIRONMENTAL CONDITIONS
}

\author{
El-Marakby'1, A.M.; Afaf, M. Tolba1; S.H. Saleh'1; F.S. Abdel Samie ${ }^{2}$ and \\ Y.A. El-Gabery ${ }^{1}$ \\ 1- Department of Agron., Fac. of Agric., Ain Shams University, Cairo, Egypt \\ E-mail: shsk_shsk@yahoo.com \\ 2- Department of Agron., Fac. of Agric., Fayoum University, Egypt
}

Keywords: Bread wheat (Triticum aestivum, L), Genotypes, Sowing dates, Locations, Biofertilizer and Phenotypic stability

\begin{abstract}
Seventeen genotypes $(G)$ of bread wheat (14 promising lines and 3 commercial cultivars) were evaluated for mean performance and stability of grain yield/plant, grain protein content and dry gluten percentage under 16 environments (two locations (L), two sowing dates(D) and four fertilization treatments $(F)$ ). The results confirmed the existence of considerable genetic variation among genotypes and their performance was significantly affected by different environments for the studied traits. Kalubia locations recorded the highest mean values for grain yield/plant while; Fayoum location recorded the highest mean values for the two quality traits. Yield and quality traits were significantly increased on early (recommended) sowing dates at Kalubia and Fayoum locations than on late sowing dates. Applying biofertilizer only gave the lowest mean performance in all traits, but adding mineral $\mathrm{N}$ besides biofertilizer markedly increased grain yield/plant and the two quality traits. However, insignificant differences existed between the rate of nitrogen recommended ( $80 \mathrm{~kg} \mathrm{~N} / \mathrm{fed}$.) and the rate of (biofertilizer $+60 \mathrm{kgN} / \mathrm{fed}$.), indicating that biofertilizer could be efficient in reducing costs of the expensive mineral $\mathrm{N}$ and reducing environmental pollution. On an average highest values of grain yield/plant were recorded by the promising wheat lines no. $10(24.57 \mathrm{~g})$, no. $9(22.50 \mathrm{~g})$, and no. $11(21.64 \mathrm{~g})$ as compared to the best check
\end{abstract}

cultivar Giza 168. Meantime, this cultivar surpassed the other genotypes in protein and dry gluten percentages. Concerning phenotypic stability, the three superior lines no. 10, 9 and 11 gave the highest mean values $\left(x^{-}\right)$of grain/plant coupled with significant regression coefficient (bi) values higher than unity and significant deviation from regression $\left(S^{2} \mathrm{di}\right)$, thus they considered specifically adapted to favourable environments.

\section{INTRODUCTION}

Wheat is one of the most important cereal crops in terms of area and production. Egypt's total production of wheat grains in 2011/2012 season reached about 8.80 million tons resulted from about 3.24 million faddan, with an average yield of 18.58Ardab/fed., while the consumption of wheat grains is about 14 million tons (F.A.O., 2011/2012). Therefore, increasing production per unit area together with the horizontal expansion in cultivated area, especially in new reclaimed land, appears to be a possible solution for reducing the gap between wheat production and consumption and to meet the demands of progressively increasing population. Also improve the cultural practices and treatments of the available cultivars to step up their yield to its maximum. Choosing the promising lines or varieties and planting them in the proper date, as well as, in the suitable locations with applying the optimum biological and mineral nitrogen fertilizers are the most important factors affecting the productivity of wheat. Moreover, the use the biological materials along with beneficial microbes (biofertilizers) to release nutrients to crops is an 
another way for increasing sustainable production in an eco-friendly and pollution-free environment. Biofertilizers harvest atmosphere nitrogen and converts into ammonical form which is available to the plants. Many investigators reported significant effects of varying locations differing in soil type and climate on performance of wheat genotypes, such as, Seleem (2007) and Abo El-ela et al (2011). Delaying sowing dates of wheat genotypes than the proper recommended sowing date caused substantial reduction in grain yield as reported by Donaldson et al (2001), Aslam et al (2003) and Tammam and Abd El-Rady (2010). Previous investigators had found that maximum response to increasing $\mathrm{N}$ - fertilizer treatment is not linear but to a certain level and other workers found positive response to biofertilizers alone or in complementary use in suitable combination with mineral fertilizers (Abd El-Lattief, 2008; Kandil et al 2011; Ahmed et al 2012 and Radwan et al 2013.) Studies on stability of performance were performed by research workers using varying environments over different growing areas of wheat and have defined some genotypes exhibiting general or specific stability in their material, such as Hamada et al (2002), Seleem (2007) and Abo El-ela et al (2011).

The major objectives of this work are; 1 - studying performance of 14 promising bread wheat lines compared with three commercial cultivars, i.e., Sids1, Sakha93 and Giza 168 under two locations, two sowing dates and four $\mathrm{N}$-fertilization levels, 2estimating stability of genotypes for the studied traits and 3- defying the best lines, which can be used as useful genetic sources in wheat breeding programs.

\section{MATERIALS AND METHODS}

Four field experiments were carried out during 2011/2012 growing season at two locations namely; the Experimental Farm of the Faculty of Agriculture, Ain Shams University at Shalakan, Kalubia Governorate and Manshyet Demo, Fayoum Governorate, to evaluate the performance and phenotypic stability of fourteen bread wheat promising lines developed in Argon. Dep., Fac of Agric., Ain Shams Univ. by Tolba (2000) and three check cultivars namely; Sids1, Sakha93 and Giza 168 obtained from wheat Dept., Agric. Res. Cent., Giza, Egypt for grain yield/plant, grain protein content and dry gluten percentage under two sowing dates and four fertilization treatments, in each location. The physical and chemical properties of soil show that both sites are clay loam, except that Demo soil contained more sand of $26 \%$ as compared to $17 \%$ at Shalakan "Kalubia Governorate". Monthly degrees of temperature were consistently higher at Demo "Fayoum Governorate". Total rainfed during the season was $6 \mathrm{~mm}$ at Shalakan, compared to $0.8 \mathrm{~mm}$ was received at Demo. The main elements content of N, P and K at Shalakan was 1189, 2.2 and $327 \mathrm{ppm}$, respectively whereas smaller values of $622,0.2$ and $144 \mathrm{ppm}$, were determined at Demo in the same order. Preceding crop was maize (Zea mays, L) at the two locations. Genotypes were sown in two dates at each location, the early normal dates were on 14 and 20 November while the late dates were on 5 and 11 December at Kalubia and Fayoum locations, respectively. Four fertilization treatments were applied at each location as follows: 1. Biofertilizer, 2. Biofertilizer + $40 \mathrm{~kg} \mathrm{~N} / \mathrm{fed}$., 3. Biofertilizer $+60 \mathrm{~kg} \mathrm{~N} / \mathrm{fed}$. and 4 . $80 \mathrm{~kg} \mathrm{~N} / \mathrm{fed}$. as control.

Seeds were treated with inoculants in the field directly before sowing as recommended using the biofertilizer "Cerealin" which was kindly obtained from Microbial Dept. Soils, Water and Environ. Res. Inst., Agric. Res .Center, Giza, Egypt. The $\mathrm{N}_{2}$ - fixer inoculation strains of Azospirillum brazsilense and Bacillus polymyxa were used. Inoculation was performed by mixing seeds with the appropriate amounts of Cerealin (one $\mathrm{g} / 100 \mathrm{~g}$ wheat grains) using Arabic gum as adhesive material. The coated seeds were then air dried in the shade for 30 minutes and sown immediately. The mineral nitrogen fertilizer was applied as ammonium sulphate $(21.5 \% \mathrm{~N})$. It was added at a rate of 40,60 , and $80 \mathrm{Kg} / \mathrm{fed}$. in two portions. The first one $(50 \%)$ was applied after 3 weeks from sowing and the second one (50\%) was applied after 7 weeks from sowing. The mineral nitrogen fertilizer was applied just before the first and second irrigation in all studied treatments. Other cultural practices were followed as recommended for wheat production at each location.

An experiment was devoted for each sowing date. The experimental design was laid out in splitplot design with three replications for each experiment.

The fertilization treatments were assigned in the main-plots and genotypes were arranged in the sub-plots. The experimental plot consisted of two rows, each row was $3 \mathrm{~m}$ in length and $20 \mathrm{~cm}$ width. Seeds were spaced at $10 \mathrm{~cm}$ within rows and one plant was left per hill.

At harvest, random sample of 10 guarded plants from each plot was collected and data were 
recorded for the following, characters grain yield per plant $(\mathrm{g})$, grain protein content $(\%)$ which determined by using micro Kjeldahal apparatus as described in the A.O.A.C. (1995) and dry gluten content (\%) which determined, according to the standard method described by A.A.C.C. (1983). The data of the two quality traits was calculated from two replications only.

Statistical analysis for split plot design was made for each location as well as combined analysis over both locations according to Gomez and Gomez (1984). L.S.D was computed to compare differences among means of locations, sowing dates, fertilization treatments and genotypes and their interactions at $5 \%$ level. Combined analysis of variance was also made for stability analysis assuming 16 environments (2 locations $\times 2$ sowing dates $\times 4$ fertilizer treatments). Phenotypic stability was estimated by utilizing the method of Eberhart and Russell (1966).

\section{RESULTS AND DISCUSSION}

\section{A. Analysis of variance components}

Mean squares of analysis of variance over two locations, two sowing dates and four fertilization treatments for the investigated traits of seventeen bread wheat genotypes are given in Table (1). Mean squares of the main source of variation, i.e. genotypes (G) were highly significant, suggesting the presence of wide range of differences between genotypes concerning the three traits. Mean squares of the other main sources of variation, locations (L), sowing dates (D) and fertilization treatments $(F)$ were also highly significant for all traits. All the first, second and third order interactions between different factors in this study were highly significant for the studied traits, except locations $x$ sowing dates $(L \times D)$ interaction for grain yield/plant, indicating that environmental factors have prominent share in the expression of the studied traits of wheat genotypes and the importance of assessment under different environments in order to identify the best genotypes for a particular or different environments. Several investigators found significant interactions between wheat genotypes and environmental factors, such as locations, sowing dates and fertilization for one or more of wheat traits like Ismail et al (2000), ElMarakby et al (2002); Tammam and Tawfelis (2004); Menshawy (2007); Ahmed and Mohamed (2009); El-Kalla et al (2010); Osman et al (2010) and Ewais (2011).

B. Performance of wheat genotypes under different environments

\section{Grain yield/plant}

Grain yield/plant as affected by locations, sowing dates, fertilization treatments, genotypes and their interactions are presented in Table (2).

Regarding the location effects, results showed that Kalubia location yielded the highest mean values for grain yield/plant (18.24g) exceeding by about $40.74 \%$ than Fayoum location (12.96g). These differences between the two locations may be explained by the analysis of soil content prior to sowing the two locations and the data of temperature degrees which may be more favorable for Kalubia location. This finding agrees with that obtained by Ismail (1995); Sharaan et al (2001); Seleem (2007) and Abo El-ela et al (2011) who found significant effect in wheat grain yield as influenced by locations. Concerning sowing dates, results indicate that grain yield/plant was significantly increased in the case of early sowings (normal) which recorded values of 20.91 and $15.51 \mathrm{~g}$ reflecting increases of about 34.30 and $19.68 \%$ at Kalubia and Fayoum locations, respectively, comparing with their corresponding late sowings which recorded values of 15.57 and $10.42 \mathrm{~g}$ at Kalubia and Fayoum locations, respectively. The reduction in grain yield associated with delaying sowing dates might be due to the wide changes in weather conditions between the two sowing dates especially rise in the temperature during the late stage of plant growth (productive stage) in late sowing causing forced maturity of plants which indirectly reduce grain yield. These results illustrate the importance of climatic factors associated with sowing dates as temperature, rainfall, humidity, .... etc. on production of grain yield. Similar results were obtained by Aslam et al (2003) they reported that the highest mean grain yield of $5315 \mathrm{~kg} / \mathrm{ha}$ was obtained when crop was sown on $15^{\text {th }}$ November comparing with $5268 \mathrm{~kg} / \mathrm{ha}$ for sowing on $1^{\text {st }} \mathrm{De}$ cember. Also, Tammam and Abd El-Rady (2010) found that late sowing reduced grain yield/plant by (21.82 and $27.27 \%$ ) for $F_{1}$ and $F_{2}$ generation as compared with normal planting date. Values of grain yield/plant were significantly affected by different fertilization treatments at both locations. The lowest mean values of grain yield/plant were steadily obtained when the seeds were inoculated by the biofertilizer (Cerealin) alone before sowing without adding mineral nitrogen fertilization. 
Arab Univ. J. Agric. Sci., Ain Shams Univ.,

Cairo, 23(1), 75 - 89, 2015

Table 1. Mean squares of combined analysis of variance over two locations (L), two sowing dates (D) and four fertilization treatments $(F)$ for seventeen bread wheat genotypes (G) for the studied traits in 2011/2012 growing season

\begin{tabular}{|cccccc|}
\hline $\begin{array}{c}\text { Source of } \\
\text { variation }\end{array}$ & d.f & $\begin{array}{c}\text { Grain } \\
\text { yield/plant } \\
\text { (g) }\end{array}$ & d.f & $\begin{array}{c}\text { Protein } \\
\text { content } \\
(\%)\end{array}$ & $\begin{array}{c}\text { Dry gluten } \\
\text { Content } \\
(\%)\end{array}$ \\
\hline L & $\mathbf{1}$ & $5881.33^{* *}$ & $\mathbf{1}$ & $67.98^{* *}$ & $43.66^{* *}$ \\
D & $\mathbf{1}$ & $5363.62^{* *}$ & $\mathbf{1}$ & $8.66^{* *}$ & $6.5^{* *}$ \\
F & $\mathbf{3}$ & $1810.16^{* *}$ & $\mathbf{3}$ & $447.49^{* *}$ & $287.03^{* *}$ \\
DL & $\mathbf{1}$ & 0.3 & $\mathbf{1}$ & $17.05^{* *}$ & $10.66^{* *}$ \\
FL & $\mathbf{3}$ & $77.71^{* *}$ & $\mathbf{3}$ & $5.01^{* *}$ & $3.51^{* *}$ \\
FD & $\mathbf{3}$ & $37.34^{* *}$ & $\mathbf{3}$ & $11.88^{* *}$ & $7.66^{* *}$ \\
FDL & $\mathbf{3}$ & $13.450^{* *}$ & $\mathbf{3}$ & $0.72^{* *}$ & $0.41^{* *}$ \\
Error(a) & $\mathbf{4 2}$ & 0.80 & $\mathbf{3 3}$ & 0.01 & 0.01 \\
G & $\mathbf{1 6}$ & $676.90^{* *}$ & $\mathbf{1 6}$ & $8.83^{* *}$ & $5.73^{* *}$ \\
GL & $\mathbf{1 6}$ & $116.97^{* *}$ & $\mathbf{1 6}$ & $4.83^{* *}$ & $2.91^{* *}$ \\
GD & $\mathbf{1 6}$ & $59.28^{* *}$ & $\mathbf{1 6}$ & $1.98^{* *}$ & $1.32^{* *}$ \\
GF & $\mathbf{4 8}$ & $16.15^{* *}$ & $\mathbf{4 8}$ & $1.01^{* *}$ & $0.69^{* *}$ \\
GDL & $\mathbf{1 6}$ & $46.35^{* *}$ & $\mathbf{1 6}$ & $2.24^{* *}$ & $1.3^{* *}$ \\
GFL & $\mathbf{4 8}$ & $7.43^{* *}$ & $\mathbf{4 8}$ & $2.3^{\star *}$ & $1.41^{* *}$ \\
GFD & $\mathbf{4 8}$ & $6.68^{* *}$ & $\mathbf{4 8}$ & $1.18^{* *}$ & $0.73^{* *}$ \\
GFDL & $\mathbf{4 8}$ & $6.87^{* *}$ & $\mathbf{4 8}$ & $1.1^{* *}$ & $0.7^{* *}$ \\
Error(b) & $\mathbf{5 0 0}$ & 3.23 & $\mathbf{2 3 7}$ & 0.35 & 0.26 \\
\hline
\end{tabular}

** denote significant at 0.01 levels of probability.

Across locations and sowing dates, the $80 \mathrm{~kg}$ $\mathrm{N} /$ fed. gave the highest grain yield/plant followed by the biofertilizer $+60 \mathrm{~kg} \mathrm{~N} / \mathrm{fed}$. dose but no significant difference existed between the two treatments, except that the latter dose surpassed significantly the full dose $\left(80 \mathrm{~kg} \mathrm{~N} / \mathrm{fed}\right.$.) in the $2^{\text {nd }}$ planting date at Fayoum location. This indicates that biofertilizer $+60 \mathrm{~kg} \mathrm{~N} / \mathrm{fed}$. is preferable and emphasized that adding biofertilizers could be efficient in reducing mineral $\mathrm{N}$ doses especially that price of $\mathrm{N}$ fertilizer is steadily rising and biofertilizer will also reduce environmental pollution. These results were confirmed by lqtidar et al (2006); Abd El-Lattief (2008); Kandil et al (2011); Ahmed et al (2012) and Abd-Allah et al (2013). Whereas, El-Sebsy and Abd El-Maaboud (2003); Ibrahim et al (2004a) and Ewais (2011) obtained higher grain yield when seeds of wheat were inoculated than uninoculated ones. On the other hand, Ibrahim et al (2004b) indicated that inoculation wheat grains with Cerealin at the rate of $750 \mathrm{~g} / \mathrm{fed}$. was more benefit for wheat plants giving remarkable increase in grain yield/fed.

Overall means recorded in Table (2) showed that lines no. 10,9 and 11 possessed the highest values of 24.57, 22.50 and 21.64 for grain yield/plant, respectively, reflecting substantial percent increases of about 68.06, 53.90 and 48.02\% as compared with the highest yielding of the check cultivar Giza 168 (14.62 g) across all studied environments.

Third order interaction effect revealed that the highest mean value per plant was obtained by the line no. $10(38.96 \mathrm{~g})$ at Kalubia location at early sowing date when fertilized with biofertilizer $+60 \mathrm{~kg}$ $\mathrm{N} /$ fed., confirming that biofertilizers can be partially an effective substitute for about $20 \mathrm{~kg} \mathrm{~N} / \mathrm{fed}$. of mineral fertilization. On the other hand, the lowest grain yield / plant was obtained by line no. 8 $(5.46 \mathrm{~g})$ in Fayoum location at late sowing date when fertilized with biofertilizer alone. Similar results were found by several investigators such as, 
El-Marakby et al (2002); Tawfelis (2006); Swelam and Hassan (2007); Swelam et al (2010) and Abdel-Nour \& Fateh (2011) they stated that the interaction between sowing dates, genotypes and nitrogen fertilizer levels was significant for grain yield in wheat. 


\section{Protein content}

Data presented in Table (3) show that protein content (\%) was significantly affected by locations, sowing dates, fertilization treatments, genotypes and most of their interactions. With respect to location effects, data indicated that the highest mean value of this trait was obtained by Fayoum location (12.44\%) compared with Kalubia location (11.73\%) with an overall mean of $12.09 \%$. Results obtained by Ismail et al (2000) showed that locations exhibited significant effect on protein percentage. Sowing dates revealed insignificant differences for protein content between early and late sowing dates at Kalubia and Fayoum locations. Values of protein percentage were significantly affected by different fertilization treatments at both locations. Highest mean values were obtained under $80 \mathrm{~kg} \mathrm{~N} / \mathrm{fed}$. at early and late sowing dates with means of 13.83 and $12.52 \%$, respectively, at Kalubia location, while at Fayoum location, the highest values in protein percentage were produced from plants fertilized with biofertilizer $+60 \mathrm{kgN} / \mathrm{fed}$. which gave mean values of 14.02 and $13.88 \%$ in early and late sowing dates. Whereas, the lowest protein percentages were steadily obtained when plants were fertilized by biofertilizer alone in early and late sowing dates at the two locations. Insignificant differences existed between biofertilizers $+60 \mathrm{~kg} \mathrm{~N} / \mathrm{fed}$. and $80 \mathrm{~kg} \mathrm{~N} / \mathrm{fed}$. (full dose) treatments under both sowing dates at the two locations, indicate that biofertilizers could be compensate the reduction in mineral fertilization. Similar results were obtained by Allam (2005); lqtidar et al (2006); Gafaar (2007) and Ahmed et al (2012) who reported that wheat grain protein content was increased with increasing nitrogen levels. Also, Abd-Allah et al (2013) found grain protein was increased due to mineral and biofertilization treatments in Sakha 69 and Gemmiza 10 cultivars. Performance of the seventeen wheat genotypes showed different responses to the different environments. Check variety Giza 168 recorded the highest protein content than the other genotypes across environments with a mean value of $13.11 \%$ followed by line no. 7 which gave a mean value of $12.75 \%$. Sial et al (2005) and El-Kalla et al (2010) found that wheat genotypic responses were almost similar and in the same direction. Concerning third order interaction effect, the results revealed that the highest mean values were obtained by the commercial variety Giza 168 (15.29\%), line no. 1(15.23\%) and line no. $12(15.13 \%)$ at Fayoum location in the early sowing date when fertilized with biofertilizers $+60 \mathrm{~kg}$
$\mathrm{N} /$ fed. On the contrary, the lowest mean value was obtained by line no. 5 (6.61\%) at Kalubia location in the early sowing date when fertilized with biofertilizers alone. Wide variability among wheat genotypes for protein percentage at different environments were reported by several workers such as; Allam (2005); El-Sayed et al (2005); Gafaar et al (2007) and Abd El-Lattief (2008).

\section{Dry gluten content}

Results of dry gluten percentage of seventeen wheat genotypes as affected by locations (L), sowing dates (D), fertilization treatments $(F)$, genotypes (G) and their interactions are present in Table (4). Regarding to the effect of locations, data revealed that Fayoum location was significantly higher in dry gluten percentage $(9.97 \%)$ than Kalubia location $(9.41 \%)$. This finding agrees with that obtained by Ismail et al (2000) who showed that locations exhibited significant effect on gluten percentage. Concerning the sowing dates, results indicated that dry gluten percentage was not significantly affected by different sowing dates at the two locations. Effect of fertilization treatments on dry gluten percentage showed clearly significant differences under early and late sowing dates at the two locations. At Kalubia location, the highest values in dry gluten percentage produced from plants fertilized with $80 \mathrm{~kg} \mathrm{~N} / \mathrm{fed}$. which gave mean values of 11.10 and $10.03 \%$ on early and late sowing dates. Whereas at Fayoum location, results showed highest mean values in dry gluten percentage produced from plants fertilized with biofertilizer $+60 \mathrm{kgN} / \mathrm{fed}$. which gave mean values of 11.25 and $11.10 \%$ on early and late sowing dates than $80 \mathrm{kgN} / \mathrm{fed}$. No significant differences were detected between the two treatments; biofertilizer + $60 \mathrm{kgN} / \mathrm{fed}$. and $80 \mathrm{~kg} \mathrm{~N} / \mathrm{fed}$. at early and late sowing dates at Kalubia and Fayoum locations. The lowest values in dry gluten percentage were produced from plants fertilized with biofertilizers alone which gave mean values of 7.18 and $7.34 \%$ in early and late sowing dates at Kalubia location and 7.77 and $8.23 \%$ in early and late sowing dates at Fayoum location. Performance of the seventeen wheat genotypes showed different responses to the different environments. Overall mean showed that the check variety Giza 168 recorded the highest dry gluten content (10.47\%) followed by the line no. $7(10.23 \%)$ surpassing the other genotypes at overall environments. All the first, second and third order interactions were significant for this trait. Concerning third interaction effect, the results 
revealed that the promising line no. 1 produced the highest dry gluten content $(12.39 \%)$ at Fayoum location and early sowing date when fertilized with biofertilizer $+60 \mathrm{~kg} \mathrm{~N} / \mathrm{fed}$. While line no. 5 gave the lowest value of $5.30 \%$ at Kalubia location at early sowing date with only biofertilizer treatment.

\section{B. Phenotypic stability}

Significance of mean squares due to different sources of variation of combined analysis over sixteen environments are presented in Table (5). The mean squares of environments $(E)$ were highly significant for all studied traits, suggesting that the environments affected differently the wheat studied traits. The mean squares genotypes $(G)$ were found to be highly significant, reflecting the presence of genetic diversity among genotypes regarding characters. Highly significant $\mathrm{G} \times \mathrm{E}$ interaction was detected for all characters which provide evidence that the genotypes differed in their responses to the various environmental conditions $(E)$. The linear effect of environments and genotypes $x$ environment interaction exhibited highly significant variation. The pooled deviation from regression was highly significant for grain yield/plant and the two quality traits. This indicated that the wheat genotypes differed considerably with respect to their stability across the investigated environments. The mean squares due to deviation from regression of all genotypes for studied traits showed wide variability. In other words, these deviation varied widely in significance and magnitudes. These results proved that the investigated wheat genotypes responded differently to the tested environments, suggesting the inconsistency performance of these genotypes over the sixteen environments. In this respect, significant differences among environments, genotypes and $G \times E$ interaction items were recorded for grain yield by many researchers like, Ismail et al (2000); Sharaan et al (2001); Hamada et al (2002); Seleem (2007) and Abo El-ela et al (2011).

\section{Stability parameters}

The mean performance as well as regression coefficients bi and deviation from regression $S^{2} d$ as two parameters of stability of wheat genotypes across the 16 environments are presented in Table (6). According to Eberhart and Russell
(1966) method, these parameters are useful to identify the adapted genotypes.

\section{1- Grain yield/plant}

Table (6) showed that the mean values across environments for grain yield/plant ranged from $12.09 \mathrm{~g}$ for the line no. 3 to $24.57 \mathrm{~g}$ for the line no. 10 with an average of $15.60 \mathrm{~g}$. The estimates of phenotypic stability parameters for grain yield/plant indicated that, bi values were not significant for the lines no. 4, 5, 6, 12, 13 and 14 and the cv. Sids 1, indicating general adaptability of these genotypes across all environments. Genotypes that may be recommended for poor environments (had bi values less than unity) included the genotypes no.1, 2, 3 and Sakha 93, whereas the other genotypes that may be recommended for favourable environments (had bi values higher than unity) comprised the lines no. 7, 8, 9, 10, and $11 . S^{2}$ di values significantly differed from zero for 12 out of the 17 genotypes studied, indicating their instability, while genotypes no. 1, 6, 13, Sakha 93 and Giza 168 gave $S^{2}$ di values that did not differ significantly from zero, considering these genotypes as the most stable ones for grain yield /plant across all environments. It is worthy to note that the three superior promising lines no.10, 9 and 11prodused the highest grain yield /plant mean values of 24.57 , 22.50 and $21.64 \mathrm{~g}$, respectively. These values exceeded the other lines as well as the highest yielding check cultivar Giza 168 (14.62 g/plant) by about $68.06,53.90$ and $48.02 \%$, respectively. The three lines had bi values higher than unity being adapted to favourable environments, thus considered desired and deserve to be propagated and released for growing in favourable environments, especially in early sowing dates at both locations with application of suitable fertilizer level (biofertilizer $+60 \mathrm{~kg} \mathrm{~N} / \mathrm{fed}$.) as previously discussed in (Table 2). Many investigators recorded similar or dissimilar trends since they used different genotypes or environmental renditions. Ismail (1995) found that intermediate yielding wheat genotypes were stable for yield, meanwhile, the highest yielding genotypes (Giza 164 and Sakha 69) were unstable. Ghanem et al (1996) indicated that the regression line slope (bi) for Sids1 was insignificant in Upper and North Delta indicating stability of this cultivar in these two zones. Hamada et al (2002) revealed that the cultivars, Sakha 93 and Giza 168 were stable and performed consistently over environments. 
Table 5. Mean squares of stability analysis of variance for characters studied of seventeen wheat genotypes

\begin{tabular}{|c|c|c|c|c|}
\hline Source of variation & d.f & $\begin{array}{c}\text { Grain } \\
\text { yield/plant } \\
\text { (g) }\end{array}$ & $\begin{array}{c}\text { Protein } \\
\text { content } \\
(\%) \\
\end{array}$ & $\begin{array}{c}\text { Dry Gluten } \\
\text { content } \\
(\%) \\
\end{array}$ \\
\hline Genotypes (G) & 16 & $230.41^{* *}$ & $4.42^{* *}$ & $2.86^{* *}$ \\
\hline $\begin{array}{l}\text { Environment }(E)+ \\
\qquad(G \times E)\end{array}$ & 255 & $29.25^{\star *}$ & $3.73^{* *}$ & $2.38^{* *}$ \\
\hline Environment (Linear) & 1 & $5692.98^{* *}$ & $744.49^{* *}$ & $478.27^{\star *}$ \\
\hline$G \times E$ (linear) & 16 & $5.33^{* *}$ & $1.19^{* *}$ & $0.74^{* *}$ \\
\hline Pooled deviation & 240 & $7.35^{\star *}$ & $0.86^{* *}$ & $0.54^{* *}$ \\
\hline 1 & 14 & $1.38^{* *}$ & $0.50^{* *}$ & $0.35^{\star *}$ \\
\hline 2 & 14 & $6.43^{* *}$ & $0.59^{* *}$ & $0.39^{* *}$ \\
\hline 3 & 14 & 8.50 ** & $1.41^{* *}$ & $0.88^{* *}$ \\
\hline 4 & 14 & $3.25^{\star}$ & $0.76^{* *}$ & $0.50^{* *}$ \\
\hline 5 & 14 & $5.44^{* *}$ & $1.33^{* *}$ & $0.84^{\star *}$ \\
\hline 6 & 14 & 1.02 & $0.37^{* *}$ & $0.23^{* *}$ \\
\hline 7 & 14 & $9.05^{\star *}$ & $0.29^{* *}$ & $0.19^{* *}$ \\
\hline 8 & 14 & $5.54^{* *}$ & $0.76^{* *}$ & $0.43^{\star *}$ \\
\hline 9 & 14 & $8.19^{* *}$ & $0.60^{* *}$ & $0.39^{* *}$ \\
\hline 10 & 14 & $12.54^{\star *}$ & $0.62^{* *}$ & $0.41^{* *}$ \\
\hline 11 & 14 & $8.33^{* *}$ & $1.41^{* *}$ & $0.94^{\star *}$ \\
\hline 12 & 14 & $3.29^{*}$ & $0.90^{* *}$ & $0.56^{* *}$ \\
\hline 13 & 14 & 2.98 & $0.90^{* *}$ & $0.56^{\star *}$ \\
\hline 14 & 14 & $6.53^{* *}$ & $1.70^{* *}$ & $0.98^{* *}$ \\
\hline Sids 1 & 14 & $4.43^{* *}$ & $0.77^{* *}$ & $0.48^{* *}$ \\
\hline Sakha 93 & 14 & 1.72 & $0.35^{\star *}$ & $0.18^{* *}$ \\
\hline Giza 168 & 14 & 1.94 & $0.15^{\star *}$ & $0.09^{* *}$ \\
\hline Pooled error & 544 & 1.83 & 0.05 & 0.03 \\
\hline
\end{tabular}

** denote significant at 0.05 and 0.01 levels of probability, respectively

\section{2- Protein content}

Mean values for grain protein content recorded in Table (6), ranged from $11.15 \%$ for the line no. 5 to $13.11 \%$ for the variety Giza 168 with an average of $12.09 \%$. As for bi stability parameter, the lines no. 3, 5, 9, 10 and the check cvs. Sakha 93 and Giza 168 have bi values did not significantly differ from unity, indicating general adaptability across environments. Genotypes having bi values less than unity and considered responsive to low productive conditions includes the lines no.1, 7, 8, 11, 14 and the cv. Sids 1, whereas, genotypes that may be recommended for high favourable environments comprised the lines no. 2, 4, 6, 12 and 13 (bi values exceed unity). On the other side, $S^{2}$ di values differed significantly from zero for all geno- types, suggesting that these genotypes show instability. The line no. 9 and Giza 168 had the highest protein percentages than grand mean (12.66 and $13.11 \%$ ), having bi values did not significantly differ from unity and lower than one $(0.89$ and $0.96)$ with $S^{2}$ di values were small $(0.55$ and 0.10$)$, thus these genotypes considered the most desired and suitable for all the studied environments. While, the line no.7 had the highest protein percentage $(12.75 \%)$, value of (bi) significantly lower than one and $S^{2}$ di value was small $(0.25)$, concerning this line as specific adaptability to unfavorable environments. These results are in agreement with those reported by Ismail et al (2000) who recorded that out of 12 genotypes A51 and K2 were the only none stable genotypes and most stable genotypes were similar in their protein content. 
Table 6. Means and stability parameters for grain yield/plant, protein content and dry gluten content of seventeen wheat genotypes

\begin{tabular}{|c|c|c|c|c|c|c|c|c|c|}
\hline \multirow{2}{*}{ Genotype } & \multicolumn{3}{|c|}{ Grain yield/plant (g) } & \multicolumn{3}{|c|}{ Protein content (\%) } & \multicolumn{3}{|c|}{ Dry gluten content (\%) } \\
\hline & $\mathbf{x}^{-}$ & bi & $\mathrm{S}^{2} \mathrm{di}$ & $\mathbf{x}^{-}$ & bi & $\mathrm{S}^{2} \mathrm{di}$ & $\mathbf{x}^{-}$ & bi & $\mathbf{S}^{2} \mathrm{di}$ \\
\hline 1 & 12.46 & $0.68^{* *}$ & -0.45 & 12.24 & $0.87^{\star}$ & $0.45^{\star \star}$ & 9.84 & $0.86^{*}$ & $0.32^{\star *}$ \\
\hline 2 & 12.12 & $0.52^{* *}$ & $4.60^{* *}$ & 11.18 & $1.20^{* *}$ & $0.54^{* *}$ & 8.98 & $1.21^{* *}$ & $0.35^{\star *}$ \\
\hline 3 & 12.09 & $0.68^{* *}$ & $6.67^{\star *}$ & 12.01 & 1.05 & $1.37^{* *}$ & 9.62 & 1.04 & $0.85^{\star *}$ \\
\hline 4 & 14.53 & 1.05 & $1.41^{*}$ & 11.79 & $1.24^{* *}$ & $0.71^{* *}$ & 9.42 & $1.22^{* *}$ & $0.47^{* *}$ \\
\hline 5 & 16.90 & 1.13 & $3.60^{* *}$ & 11.15 & 0.98 & $1.28^{\star *}$ & 8.93 & 0.98 & $0.81^{* *}$ \\
\hline 6 & 14.09 & 0.83 & -0.81 & 12.19 & $1.26^{\star *}$ & $0.32^{\star *}$ & 9.78 & $1.21^{\star *}$ & $0.20^{* *}$ \\
\hline 7 & 16.03 & $1.34^{\star *}$ & $7.22^{* *}$ & 12.75 & $0.85^{\star *}$ & $0.25^{\star *}$ & 10.23 & $0.86^{* *}$ & $0.16^{* *}$ \\
\hline 8 & 15.13 & $1.28^{*}$ & $3.71^{\star *}$ & 12.46 & $0.87^{*}$ & $0.72^{\star \star}$ & 10.01 & $0.88^{*}$ & $0.40^{* *}$ \\
\hline 9 & 22.50 & $1.37^{\star *}$ & $6.36^{\star *}$ & 12.66 & 0.89 & $0.55^{\star \star}$ & 10.15 & $0.89^{*}$ & $0.36^{* *}$ \\
\hline 10 & 24.57 & $1.49^{\star *}$ & $10.71^{* *}$ & 11.91 & 0.96 & $0.58^{\star *}$ & 9.55 & 0.95 & $0.38^{* *}$ \\
\hline 11 & 21.64 & $1.35^{\star \star}$ & $6.50^{* *}$ & 12.46 & $0.71^{* *}$ & $1.37^{\star *}$ & 10.01 & $0.70^{* *}$ & $0.91^{* *}$ \\
\hline 12 & 13.69 & 0.95 & $1.46^{\star}$ & 11.94 & $1.20^{\star *}$ & $0.86^{\star *}$ & 9.59 & $1.20^{\star \star}$ & $0.53^{* *}$ \\
\hline 13 & 15.83 & 1.11 & 1.14 & 11.64 & $1.14^{*}$ & $0.85^{\star \star}$ & 9.31 & $1.14^{*}$ & $0.53^{* *}$ \\
\hline 14 & 13.91 & 1.10 & $4.70^{* *}$ & 12.06 & $0.85^{\star \star}$ & $1.66^{\star *}$ & 9.70 & $0.86^{\star *}$ & $0.95^{\star *}$ \\
\hline Sids 1 & 12.50 & 0.85 & $2.59^{\star *}$ & 11.64 & $0.88^{\star}$ & $0.72^{\star *}$ & 9.31 & $0.88^{*}$ & $0.45^{* *}$ \\
\hline Sakha 93 & 12.60 & $0.57^{\star \star}$ & -0.11 & 12.31 & 1.12 & $0.30^{\star *}$ & 9.85 & $1.14^{*}$ & $0.15^{\star *}$ \\
\hline Giza 168 & 14.62 & $0.71^{*}$ & 0.11 & 13.11 & 0.96 & $0.10^{\star *}$ & 10.47 & 0.99 & $0.06^{* *}$ \\
\hline Mean & 15.60 & & & 12.09 & & & 9.69 & & \\
\hline LSD at $5 \%$ & 1.77 & & & 0.42 & & & 0.35 & & \\
\hline
\end{tabular}

* and ${ }^{* *}$ denote significant at 0.05 and 0.01 levels of probability, respectively.

\section{3- Dry gluten content}

Data presented in Table (6) show that mean values of genotypes for dry gluten content ranged from $8.93 \%$ for the line no. 5 to $10.47 \%$ for the check variety Giza 168 with an average of $9.69 \%$. The first stability parameter (bi) was significantly differed from unity for all genotypes, except of promising lines no. 3, 5 and 10 and the variety Giza 168 that did not significantly differ from unity, indicating similar response of these four genotypes to changes in environmental conditions and their general adaptability for this trait. On the other hand, the second stability parameter $\left(S^{2} \mathrm{di}\right)$ was significant for all genotypes, thus they considered unstable. The lines no. 7 and 9 that had high gluten percentage (10.23 and $10.15 \%)$ exhibited specific adaptability to unfavorable environments, since, their bi values significantly lesser than one (0.86 and 0.89). The variety Giza 168 had the highest gluten percentage (10.47\%) and adapted to all studied environments $(\mathrm{bi}=0.99$ ) but not stable and having the lowest $S^{2}$ di value $(0.06)$, thus this variety is consider suitable under all environments. In this respect, Ismail et al (2000) found that the lines A68, K5 and $\mathrm{K} 6$ were stable for dry gluten out of 12 wheat genotypes studied.

\section{General conclusion}

From the results of the different phases of this study, it could be concluded that 3 wheat varieties and 14 promising lines displayed differential response to the 16 environments. Effect of locations was pronounced on the three different traits of all genotypes. Kalubia location exhibited superiority in grain yield/plant. Whereas, Fayoum location exhibited superiority in the two quality traits. Earlier recommended sowing date exhibited superiority in grain yield/plant. While, quality traits were insignificant between early and late sowing dates at Kalubia and Fayoum locations. With respect to fertilization treatments, it was found that applying the biofertilizer only gave the lowest performance of studied traits, but adding mineral $\mathrm{N}$ besides biofertilizer or full dose of $\mathrm{N}$ increased grain yield/plant and the 
two quality traits. Insignificant differences were found between biofertilizer $+60 \mathrm{~kg} \mathrm{~N} / \mathrm{fed}$. and $80 \mathrm{~kg}$ $\mathrm{N} /$ fed. treatments under early and late sowing dates at Kalubia and Fayoum locations for grain yield/plant and the two quality traits. Lines no. 9, 10 and 11 exhibited superiority in grain yield/plant. Check variety Giza 168 had the highest values in quality traits. Genotypes x environment interaction and stability of each genotype performance across environments such as locations or sowing dates and $\mathrm{N}$ fertilization are of great value for drawing the policy of cultivar distribution to the area devoted for economic crops culture like wheat. Concerning phenotypic stability, each genotype showed general or specific adaptability for one or more of the studied traits. The three superior lines no. 10, 9 and 11 gave the highest mean values $\left(x^{-}\right)$of grain yield per plant coupled with significant regression coefficient (bi) values higher than unity and significant deviation from regression $\left(s^{2} d i\right)$, thus, these lines are considered desired and specifically adapted to favourable environments, and deserve to be propagated and distributed for wheat production as commercial promising varieties.

\section{REFERENCES}

A.A.C.C. 1983. American Association of Cereal Chemists. Cereal Laboratory Methods. St. Paul., Minnesota, USA.

A.O.A.C. 1995. Official Methods of Analysis, $16^{\text {th }}$ Ed. Association of Official Analysis Chemists. Washington, DC, U.S.A.

Abd- Allah, Amany M., Mahomoud, G.O. and Mohamed, H.F. 2013. Heat production and plant chemical composition under different mineral and biofertilizer treatments. J. Agric. Sci. Mansoura Univ., 4: 1119-1137.

Abd El-Lattief, E.A. 2008. Increasing bread wheat (Triticum aestivum, L.) productivity and profitability in the newly reclaimed lands through the integrated use of mineral, organic and biofertilizers. Alex. J. Agric. Res., 53(1): 47-54.

Abdel Nour, Nadya, A.R. and Hayam S. Fateh 2011. Influence of sowing date and nitrogen fertilization on yield and its components in some bread wheat genotypes. Egypt. Agric. Rec., 89(4): 1413-1433.

Abo El-ela, Sabah H., El-Shaarawy, G.A. and Wafaa A. El-Awady 2011. Yield stability of some bread wheat genotypes. Egypt . J. of Appl. Sci., 26(8): 483-496.

Ahmed, A.A., El-Henawy, A.S. and Belal, E.B. 2012. Effect of chemical nitrogen and compost rates on wheat productivity and soil properties. Minufiya, J. Agric., Res. 37(1): 123-137.

Ahmed, M.S.H. and Mohamed, S.M.S. 2009. Genetic analysis of yield and its components in diallel crosses of bread wheat (Triticum aestivum, L.) under two sowing dates. $6^{\text {th }}$ International Plant Breeding Conference, Ismalia, Egypt, May 3-5 pp. 31-52.

Allam, S.A. 2005. Growth and productivity performance of some wheat cultivars under various nitrogen fertilization levels. J. Agric. Sci. Mansoura Univ., 30(4): 1871-1880.

Aslam, M., Hussain, M., Akhtar, M., Cheema, M.S. and Ali, L. 2003. Response of wheat varieties to sowing dates. Pakistan Journal of Agronomy. 2(4): 190-194.

Donaldson, E., Schillinger, W.F. and Dofing, S.M. 2001. Straw production and grain yield relationships in winter wheat. Crop Sci., 41: 100106.

Eberhart, S.A. and Russell, W.A. 1966. Stability parameters for comparing varieties. Crop Sci., 6: 36-40.

El-Kalla, S.E., Leillah, A.A., El-Emery, M.I. and Kishk, A.M.S. 2010. Performance of some wheat (Triticum aestivum L.) cultivars under late sowing in newly reclaimed soils. J. Plant Production, Mansoura Univ., 1(5): 689-697.

El-Marakby, A.M., Mohamed, A.A., Afaf, M. Tolba and Saleh, S.H. 2002. Performance and stability of some promising wheat lines under different environmental conditions. Egypt. J. Plant Breed. 6(1): 43-68.

El-Sayed, M.Z., Abd El-Sattar, A.E., Basha, H.A. and Abd El-Hammeed, I.M. 2005. Improvement of wheat productivity in newly reclaimed soil in Egypt. Annals UMCS, Sec. E. 60: 113121.

El-Sebsy, A.A. and Abd El-Maaboud, M.Sh. 2003. Wheat response to mineral and biological nitrogen fertilizers under rainfed and supplementary irrigation condition. Alex. Sci. Exch., 24(3): 313-326.

Ewais, Magda, A. 2011. Effect of biofertilization, mineral and foliar application of micronutrients on growth, yield and chemical contents of wheat plants. Egypt. J. Appl. Sci. 26(8): 444471.

F.A.O. 2012. Food and Agriculture Organization of United Nations. Available at http://www.F.A.O.org.

Gafaar, N.A. 2007. Response of some bread wheat varieties grown under different levels of planting density and nitrogen fertilizer. Minufiya. J. Agric. Ryes., 32(1): 165-183. 
Ghanem, E.H., Abd El-Shafi, A.M., Hanna, N.S., Mahomoud, S.K., Sabry, S.R.S., Abd ElHalim, M.M., Zaid, H.M.M., Moussa, A.M., Abd El-Majead, S.A. and Sherif, S. 1996. Grain yield and stability of the new bread wheat (Triticum aestivum, L.) cultivar Sids I in different agroclimatic zones of Egypt. Bull. Fac. Agric. Unvi., Cairo, 47: 565-575.

Gomez, K.A. and Gomez, A.A. 1984. Statistical Procedures for Agricultural Research. $2^{\text {nd }}$ ed., pp. 97-107, John Wiley \& Sons, New York, USA.

Hamada, A.A., Abo-Warda, A.M.A., Hendawy, H.A. and Abd El-Aleem, M.M. 2002. Yield stability of some Egyptian newly released bread wheat cultivars. Manufiya J. Agric. Res., 27(6): 1377-1389.

Ibrahim, E.M., Bassal, S.A.A. and Bader, M.M.A. 2004a. Effect of tillage systems, fertilization and spraying urea on wheat productivity. Zagazig, J. Agric., Res., 31(2): 491-507.

Ibrahim, E.M., El-Shamarka, S., Selim, A.H., Gaffaar, N.A. and El-Fiki, S.F. 2004b. Response of some new wheat genotypes to different levels of nitrogen fertilization. Egypt. J. Appl. Sci., 19(11): 215-262.

lqtidar, H., Ayyazkhan, M. and Ahmedkhan, E. 2006. Bread wheat varieties as influenced by different nitrogen levels. J. Zhejiang, Univ. Sci. B., 7(1): 70-78.

Ismail, A.A. 1995. The performance and stability of some wheat genotypes under different environments. Assiut. J. Agric. Sci., 26(4): 15-37.

Ismail, A.A., Abou-Salama, A.M., Teama, E.A. and Kheiralla, K.A. 2000. Stability of some wheat (Triticum aestivum, L.) lines quality traits. Assiut. J. Agric. Sci., 31(1): 119-136.

Kandil, A., El-Hindi, M.H., Badawi, M.A., ElMoursy, S.A. and Kalboush, F.A.H.M. 2011. Response of wheat to rates of nitrogen, bio fertilizers and land leveling. Crops Environment, 2(1): 46- 51.

Menshawy, A.M.M. 2007. Evaluation of some early bread wheat genotypes under different sowing dates: 1. Agronomic characters. Proceeding Fifth Plant Breed. Conf. May 27. Egypt. J. Plant Breed. Special Issue., 11(1): 41-55.

Osman, S.S., Khalil, H.A., Mohamed, A.A. and Saleh, S.H. 2010. Performance and combining ability for grain yield and its components in diallel crosses of bread wheat under different sowing dates. Egypt. J. Plant Breed. 14(1): 261-285.
Radwan, F.I., Gomaa, M.A., Nasser, M.A., Kandil, E.E. and Lamlom, S.F. 2013. Effect of sowing methods and bio-organic fertilization on growth, yield and yield components of wheat (Triticum aestivum, L.). Research Journal of Agriculture and Biological Sciences, 9(1): 70-78.

Seleem, S.A. 2007. Analysis of phenotypic stability for grain yield and its components in bread wheat. J. Agric. Sci. Mansoura Univ., 32(4): 2403-2420.

Sharaan, A.N., Ghallab, K.A. and Ghabour, S.K. 2001. Genotype-environment interaction, yield performance and stability of wheat varieties grown in diverse environments. Egypt. J. Plant Breeding. 5: 137-154.

Sial, M.A., Arain, M.A., Khanzada, S., Naqvi, M.H., Dahot, M.U. and Nizamani, N.A. 2005. Yield and quality parameters of wheat genotypes as affected by sowing dates and high temperature stress. Pakistan J. of Bot., 37(3): 575-584.

Swelam, A.A. and Manal, A. Hassan 2007. Response of some bread wheat cultivars to sowing date and potassium fertilization. Egypt. J. Appl. Sci., 22(11): 477-491.

Swelam, A.A., Eman S. Mohamed and Hala, S. Sayed, 2010. Effect of sowing date and nitrogen fertilization levels on productivity and technological qualities of some bread wheat genotypes. Egypt. J. of Appl. Sci., 25(11): 472485.

Tammam, A.M. and Abd El-Rady, A.G. 2010. Inheritance of yield and its components in some bread wheat (Triticum eastivum) crosses under heat stress. Egypt. J. Agric. Res., 88(4): 1239 - 1257.

Tammam, A.M. and Tawfelis, M.B. 2004. Effect of sowing date and nitrogen fertilizer levels in relation to yield and yield components of durum wheat (Triticum turgidum, var. durum) under upper Egypt environments. J. Agric. Sci. Mansoura Univ., 29(10): 5431-5442.

Tawfelis, M.B. 2006. Stability parameters of some bread wheat genotypes (Triticum aestivum, L.) in new and old lands under Upper Egypt conditions. Egypt J. Plant Breed, 10(1): 223-246.

Tolba, Afaf M. 2000. Evaluation of different bread wheat lines in the $F_{6}$ and $F_{7}$ generation for grain yield and its attributes. J. Agric. Sci., Mansoura Univ., 25(10): 6061- 6073. 